Release Study Group. Clinical efficacy and tolerability of a new levodopa/benserazide dual-release formulation in Parkinsonian patients. Clin Neuropharmacol 1997;20:130-139.

5. Lees AJ. The relevance of Lewy body to the pathogenesis of idiopathic Parkinson's disease. J Neurol Neurosurg Psychiatry 1988;51:144-147.

6. Fahn S, Elton R, and Unified Parkinson's Disease Rating Scale Development Committee. Unified Parkinson's Disease Scale. In: Fahn S, Marsden CD, Calne D, eds. Recent developments in Parkinson's disease, vol 2. New York: Raven Press, 1987:153-163.
7. Durif F, Vidailhet M, Assal F, Roche C, Bonnet AM, Agid Y. Low-dose clozapine improves dyskinesia in Parkinson's disease. Neurology 1997;48:658-662.

8. Heinzel G, Woloszczak R, Thomann P, eds. TopFit 2.0 pharmacokinetic and pharmacodynamic data analysis system for the PC. Stuttgart: Fischer, 1993.

9. Hills M, Armitage P. The two-period cross-over clinical trial. Br J Clin Pharmacol 1979;8:7-20.

10. Crevoisier CH, Hoevels B, Zürcher G, Da Prada M. Bioavailability of levodopa after Madopar LP administration in healthy volunteers. Eur Neurol 1987;27(suppl 1):36-46.

\title{
Neuro/mages
}

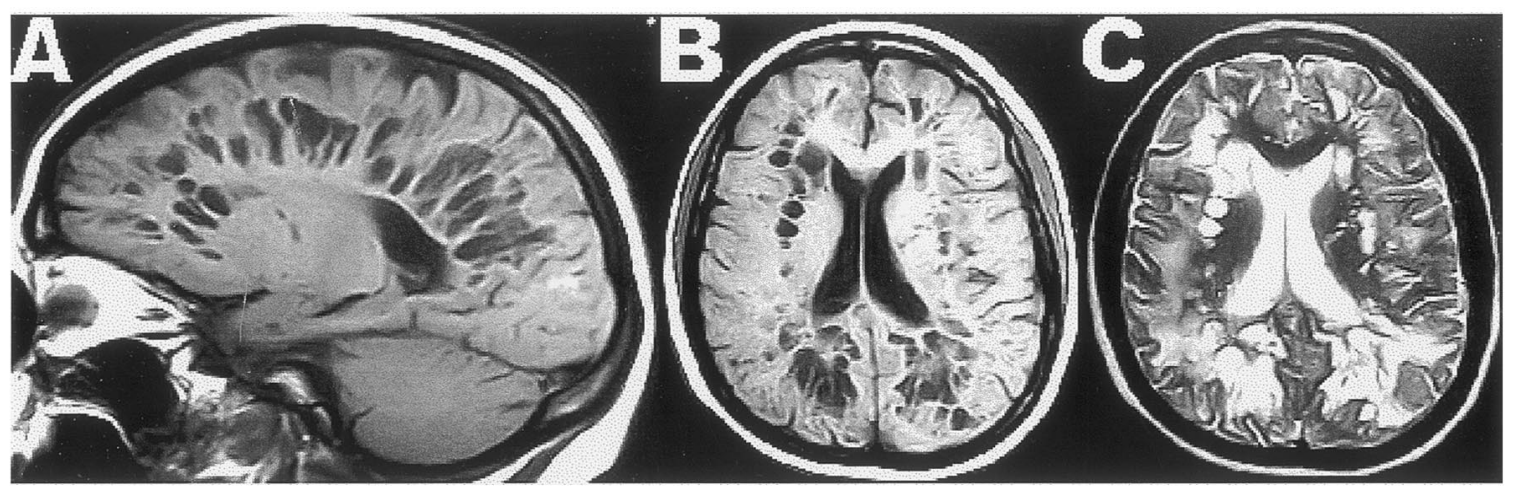

Figure. Sagittal T1-weighted imaging (A) identifies multiple tubular structures in the distribution of the perforating arteries. They are differentiated from lacunae by their location, lack of peripheral hyperintensity on fluid-attenuated inversion recovery (FLAIR) images (FLAIR images [B] and T2-weighted images [C]), and convergence toward the ventricles (A-C).

\section{Unusually prominent perivascular spaces}

G.R. Eichhorn, MD, Z. Ammache, MD, W. Bell, MD, W.T.C. Yuh, MD, Iowa City, IA

A 50-year-old right-handed woman was referred for evaluation of abnormal MRI studies (figure) that were obtained because of a 2-month history of left ear pain, which had resolved in the interim. Results of neurologic and comprehensive neuropsychologic evaluation were normal.

Virchow-Robin spaces (VRS) are perivascular extensions of the pia mater accompanying the perforating arteries (but not the veins) of the brain. VRS can be seen at any age but tend to enlarge with aging. ${ }^{1}$ Prominent
VRS also occur in the periventricular and supraventricular white matter and rarely mimic pathologic lesions, ${ }^{2}$ such as cystic infection, mucopolysaccharidosis, lacunar infarction, and MS.

1. Heier LA, Bauer CJ, Schwartz L, Zimmerman RD, Morgello S, Dec MD. Large Virchow-Robin spaces: MR-clinical correlation. AJNR Am J Neuroradiol 1989;10:929-936.

2. Ogawa T, Okudera T, Fukasawa H, et al. Unusual widening of VirchowRobin spaces: MR appearance. AJNR Am J Neuroradiol 1995;16:12381242 . 


\section{Neurology}

Unusually prominent perivascular spaces

G.R. Eichhorn, Z. Ammache, W. Bell, et al.

Neurology 2001;56;1242

DOI 10.1212/WNL.56.9.1242

\section{This information is current as of May 8, 2001}

Updated Information \& Services

References

Permissions \& Licensing

Reprints including high resolution figures, can be found at: http://n.neurology.org/content/56/9/1242.full

This article cites 2 articles, 1 of which you can access for free at: http://n.neurology.org/content/56/9/1242.full\#ref-list-1

Information about reproducing this article in parts (figures,tables) or in its entirety can be found online at:

http://www.neurology.org/about/about_the_journal\#permissions

Information about ordering reprints can be found online: http://n.neurology.org/subscribers/advertise

Neurology ${ }^{\circledR}$ is the official journal of the American Academy of Neurology. Published continuously since 1951, it is now a weekly with 48 issues per year. Copyright. All rights reserved. Print ISSN: 0028-3878. Online ISSN: 1526-632X.

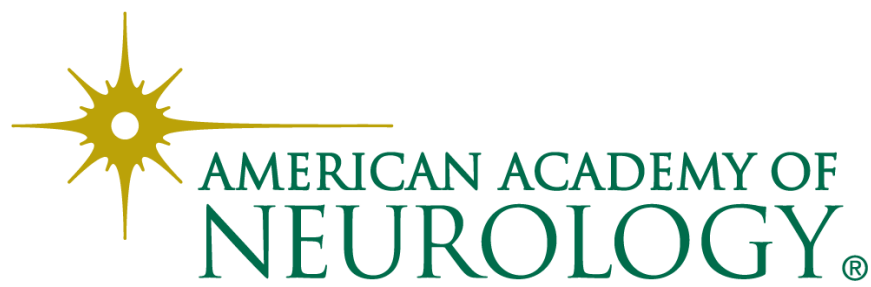

